\title{
Modificación de Estatutos Sociedad de Cirujanos de Chile. Octubre 2010
}

\author{
Amendment of Bylaws
}

Por mucho tiempo los Directorios de nuestra Sociedad de Cirujanos de Chile, la organización más grande de cirujanos acreditados del país, han sentido y deseado generar la modificación de los Estatutos vigentes desde 1955, como la única forma de producir cambios que permitieran aumentar su base societaria para hacerla más representativa y sustentable, y democratizar el mecanismo de renovación de sus autoridades, generando así un Directorio que refleje los intereses de los socios.

En agosto del año 2002, el Directorio presidido por el Dr. Julio Yarmuch organizó la Jornada de Planificación Estratégica en Quillón (VIII Región), el que contó con la participación de miembros destacados de la Sociedad de Santiago y un grupo selecto y numeroso de cirujanos de Concepción, Chillán y Los Angeles, surgiendo allí el esbozo de la propuesta de las anheladas modificaciones. En reuniones posteriores estas fueron maduradas, y el Directorio de 2003, presidido por el Dr. Augusto León, las sometió a votación en una Sesión Extraordinaria, realizada en Viña del Mar, con la presencia de un Abogado y Notario Público y de un número significativo de socios, siendo todas las modificaciones propuestas aprobadas por amplia mayoría.

Seis años y sus respectivos Directorios pasaron, realizando todos ellos infructuosos esfuerzos para conseguir un trámite expedito en el Ministerio de Justicia; me tocó participar activamente como Director con los Drs. Julio Yarmuch y Augusto León, como Vice Presidente el Dr. Alberto Gyhra (2004), como Presidente (2005) y como Past President con el Dr. Fernando Ibáñez (2006); pero a pesar de todo nuestro esfuerzo para conseguirlo, no avanzamos nada, pasando lo mismo con los Drs. Braghetto (2007), Hepp (2008) y Bannura (2009), hasta que el Directorio de 2010, presidido por nuestra primera mujer Presidenta, la Dra. Jamile Camacho, lograra su aprobación definitiva, en el mes de octubre del año de su mandato, a un mes del Congreso de Pucón de noviembre de 2010 cuando se renovaría el Directorio.

De los aspectos más importantes de la modificación de los Estatutos recientemente aprobados, se puso en vigencia de inmediato, las facilidades para que los Miembros Afiliados pasaran a ser Miembros Titulares, cumpliendo con el objetivo de aumentar la base societaria para hacerla más representativa y sustentable; y el mismo Directorio 2010 diseñó, tras múltiples reuniones extraordinarias, el Reglamento de Elecciones de Directorio para renovar el Directorio 2011-2012, que sería aplicado en las Elecciones a realizarse en el Congreso de Pucón 2010.

Este segundo punto tan importante, ligado al objetivo de la democratización del mecanismo de renovación del Directorio, se vió perturbado por la obligación legal de aplicarlo en las elecciones programadas a sólo 45 días de su aprobación, y por haber incluido en esa obligación legal, al Reglamento de Elecciones de Directorio generado con tanta premura.

El artículo $30^{\circ}$ de los estatutos, no incluído en la modificación recién lograda, le otorga al Directorio la facultad de confeccionar los reglamentos que rigen el quehacer de nuestra Sociedad, pero "ellos podrán ser modificados por directorios venideros sin necesidad de una asamblea extraordinaria”.

Este último acápite dará tiempo para revisar y enriquecer el Reglamento de Elecciones de Directorio, de modo que refleje el espíritu de los Estatutos y posibilite elecciones representativas y democráticas.

Dr. Federico Hernández F. Jefe de Servicio de Cirugía Hospital Barros Luco-Trudeau

Santiago, Marzo 28 de 2011 